logos_i_ethos_2017_(45)_numer specjalny, s. 7-28

DOI: http://dx.doi.org/10.15633/lie.2335

Magdalena Żardecka

Uniwersytet Rzeszowski

\title{
Znaczenie rozsądku i umiaru w życiu jednostki i społeczeństwa
}

Rozsądek oraz umiar to dwie spośród czterech (obok sprawiedliwości i męstwa) cnót zwanych kardynalnymi (czyli zawiasowymi), na których opiera się całe życie moralne człowieka. Cnoty te cenione są od czasów starożytnych, przenikają duchowość średniowiecza, obowiązują również w świecie nowożytnym, jednakże od drugiej połowy XX wieku

Magdalena Żardecka, dr hab., prof. Uniwersytetu Rzeszowskiego, Zakład Antropologii Kulturowej UR. Zainteresowania naukowe: filozofia społeczna, filozofia polityczna, filozofia współczesna. Ważniejsze publikacje: Wspólnota i ironia. Richard Rorty i jego wizja społeczeństwa liberalnego, Lublin 2003; Rozum i obywatel. Idea rozumu publicznego oraz koncepcja jednostki we wspótczesnej filozofii polityki, Rzeszów 2007. przeżywają kryzys i popadają w coraz większe zapomnienie. Cnota polegała zawsze na wyznaczaniu sobie granic - a tego współczesny człowiek bardzo nie lubi - oraz na przestrzeganiu zasad - co wydaje się nowoczesnemu indywidualiście rodzajem etycznego terroru. Popularne dziś hasła nawołują do wolności, autentyczności i bezkompromisowego bycia sobą, a także do nieograniczonej konsumpcji różnych dóbr. Nie oznacza to podążania drogą cnoty.

W niniejszym artykule będzie zaprezentowana klasyczna koncepcja cnoty oraz (w wielkim skrócie) antyczna i średniowieczna etyka cnót; następnie przedstawione zostaną cnoty rozsądku i umiarkowania w wersji proponowanej przez wybranych filozofów oraz w ujęciu typowym dla antycznej tragedii, pokazane też zostaną alegoryczne wyobrażenia tych dwóch przymiotów charakteru. W drugiej części tekstu przejdziemy do rozważań dotyczących współczesnego społeczeństwa, które odrzuca samą ideę cnoty (kryzys etyki cnót), a uprzywilejowuje takie cechy ludzkie, 
które w klasycznym ujęciu byłyby traktowane jako wady. W konkluzji sformułowany zostanie wniosek, że dawno zapomniane i porzucone cnoty rozsądku i umiaru są tym, czego najbardziej brakuje schorowanym egoistycznym jednostkom i zatomizowanemu, pełnemu rozmaitych napięć społeczeństwu.

\section{Pojęcie cnoty}

„Cnota” (grec. arete, łac. vitus) w starożytnej Grecji oraz w tradycji chrześcijańskiej oznaczała dzielność, mężność, siłę, a także sprawność i łatwość w wykonywaniu stosownych dla człowieka czynności i działań. W węższym sensie cnota definiowana była jako stała skłonność i sprawność woli (charakter) w czynieniu moralnego dobra (realizowaniu moralnych wartości) ${ }^{1}$. Kształtowanie w sobie cnoty (wyrabianie charakteru) było jednym z najważniejszych etycznych zagadnień od czasów starożytnych. Znaczenie tego pojęcia ulegało jednak stopniowym przekształceniom, aż do stanu, w którym zostało zawężone do czystości seksualnej i dziewictwa.

Sokrates twierdził, że cnota jest wiedzą, którą każdy może i powinien w sobie odkryć. W dialogach Platona jego postać pojawia się jako ucieleśnienie wszelkiej cnoty (mądrości i rozwagi w szczególności). Platon wyróżnił cztery cnoty podstawowe: trzy z nich - mądrość, odwaga i umiarkowanie - są doskonałościami trzech części duszy (rozumnej, popędliwej i pożądliwej) oraz przymiotami poszczególnych warstw społecznych (arystokracji, żołnierzy i rzemieślników), czwarta zaś - sprawiedliwość - odpowiada za harmonię całości. W ujęciu Arystotelesa cnota była moralną sprawnością, utrwaloną dyspozycją, uporządkowaną postawą czyniącą człowieka zdolnym do czynów moralnie dobrych oraz sprawiającą, że jego życie emocjonalne staje się należyte ${ }^{2}$. Człowiek cnotliwy pragnie

1 Zob. J. Herbut, Cnota, w: Leksykon filozofii klasycznej, red. J. Herbut, Lublin 1997, s. 90-91.

2 „Dlatego trzeba od wczesnej młodości być wdrażanym poniekąd, jak mówi Platon, do radości i zmartwienia z powodu tych rzeczy, którymi należy się cieszyć i martwić; na tym bowiem właśnie polega należyte wychowanie”; „niemałą bowiem rzeczą dla działania jest należyty lub nienależyty sposób doznawania przyjemności i przykrości" (Arystoteles, Etyka nikomachejska, przeł. D. Gromska, 
tego, co należy, i w należyty sposób, ponieważ emocjonalna część jego duszy została uformowana zgodnie z rozumem. Cnota jest umiejętnością wybierania celu właściwego ze względu na nasze dobro, jest zdolnością doprowadzania do stanu, w którym mamy się dobrze. Arystoteles określał ten stan mianem eudajmonii.

Starożytni myśliciele uważali, że życie cnotliwe to najdoskonalszy sposób egzystencji, do jakiego człowiek jest zdolny ze swej natury. Postępowanie zgodne $\mathrm{z}$ wymaganiami cnoty to postępowanie zgodne $\mathrm{z}$ naturą ludzką. Wszelkie wady natomiast stanowią wynaturzenie i sprzeciwiają się rozumowi. Cnota traktowana była jako naturalna możność duszy, która uaktualnia się przez wyrabianie nawyków. Starożytni wierzyli, że człowiek jest twórcą swego charakteru. Cnoty są dobrami wewnętrznymi, których nie można w pełni poznać ani osiągnąć inaczej niż przez praktykowanie; stanowią też trwały element tradycji przekazywany w procesie wychowania (paideia). Starożytni filozofowie (Sokrates, Platon, Arystoteles) uważali, że spontaniczne pragnienia i lęki nie mogą być drogą do rozpoznania prawdziwego dobra i zła. Cnoty, czyli dobra wewnętrzne osiągnięte przez człowieka nie stają się nigdy przedmiotem rywalizacji ani zazdrości ze strony innych ludzi (jak to się dzieje w przypadku dóbr zewnętrznych). Są one dobrem jednostki, które zarazem w najwyższym stopniu służy wspólnocie. Człowiek żyjący według standardów starożytnych chce odkryć najpiękniejszy kształt skrywający się w jego własnej naturze po to, by rzeczywiście osiągnąć apogeum swych możliwości. Musi zatem w pewnym sensie i do pewnego stopnia znać uprzednio zarys postaci, której kształtu w sobie poszukuje (jak rzeźbiarz wykuwający posąg w kamieniu). Cnota wymaga i zakłada pewien poziom wiedzy, która w konsekwencji prowadzi do skutków praktycznych (zbudowania w sobie cnoty) oraz do poszerzenia i umocnienia tejże wiedzy (skutki teoretyczne).

w: Arystoteles, Dzieła wszystkie, t. 5, przeł. D. Gromska, L. Regner, W. Wróblewski, Warszawa 1996, s. 107, 108). Arystoteles stworzył teorię etyczną, która do dziś nie straciła aktualności, zdefiniował i podzielił cnoty, stworzył listę cnót charakteryzujących wspólnotę, w której żył, zaproponował teorię wychowania polegającą na kształtowaniu charakteru. 
Cnota to duchowa dyspozycja realizująca się i uzewnętrzniająca w czynach (wymagająca aktywności, niemożliwa do osiągnięcia, gdy człowiek pozostaje bierny) ${ }^{3}$. Stoicy kontynuowali, a nawet zradykalizowali etykę cnót. Stworzyli etykę wzorców osobowych (ideał mędrca) wyznaczających kierunek duchowych postępów ${ }^{4}$. Zaproponowane przez nich ideały (np. samowystarczalność - autarkeia) okazały się nieosiągalne dla zwykłego człowieka (ale stoicy nie twierdzili, że filozofia jest szkołą życia dla mas) ${ }^{5}$.

Zarówno w starożytności, jak i w średniowieczu cnota uważana była za jeden z czynników doskonałości osobowej, stanowiła wyraz człowieczeństwa danej jednostki, jej szlachetności i moralnej wartości ${ }^{6}$. Myśliciele antyczni uważali, że cnoty są wynikiem wychowania i pracy nad sobą (kształtują się w wyniku wielokrotnego powtarzania). Myśl chrześcijańska zasadniczo zgodziła się z nimi, gdy chodzi o rolę wychowania i pracy nad sobą w kształtowaniu moralnej postawy człowieka. Podkreślała jednak, że praca nad sobą to dramatyczna walka jednostki z naturalną dla niej skłonnością do zła. Walka ta byłaby beznadziejna, gdyby nie pomagał nam w niej Bóg. Chrześcijaństwo stanęło na stanowisku, że choć mamy obowiązek pracy nad sobą, to jednak nie jesteśmy twórcami własnych cnót, lecz zawdzięczamy je Bogu, który tworzy w nas i umacnia wszystko, co dobre i wartościowe ${ }^{7}$.

Chrześcijaństwo do starożytnego repertuaru cnót dołączyło trzy cnoty teologiczne (teologalne) - wiarę, nadzieję i miłość, których specyfika polega na tym, że człowiek w ogóle nie może ich w sobie ukształtować, lub może, ale w bardzo ograniczonym stopniu. W przypadku wiary, nadziei i miłości osobisty wysiłek albo jest zupełnie jałowy, albo stanowi zaledwie warunek wstępny osiągnięcia celu. Przy największej pracy nad

3 Por. T. Ślipko, Zarys etyki ogólnej, Kraków 1974, s. 326-347; A. Szostek, Pogadanki z etyki, Częstochowa 1993; J. Woroniecki, Katolicka etyka wychowawcza, t. 2/1, Lublin 1986, s. 14-32.

${ }^{4}$ Por. J. M. Rist, Human Value. A Study of Ancient Philosophical Ethics, Leiden 1982, passim.

5 Na temat etyki stoików zob. np. O. Gigon, Główne problemy filozofii starożytnej, przeł. P. Domański, Warszawa 1996, s. 210.

6 Por. A. MacIntyre, Natura cnót, „Znak” 1994 nr 8 (46), s. 36-46.

7 Por. Św. Tomasz z Akwinu, Suma teologiczna w skrócie, skrót i objaśnienia F. W. Bednarski OP, Warszawa 2004, s. 271. 
sobą zawsze pozostanie coś, do czego człowiek nigdy nie będzie w stanie dosięgnąć - nikt nie może pokochać dlatego tylko, że tego pragnie, nikt nie może uwierzyć dlatego tylko, że tak postanowił. Cnoty teologiczne należą do władz moralnych i uzdolnień duchowych, które przerastają rozum i wolę człowieka. Wydają się one darowane niejako „z góry”. W teologii moralnej mówi się, że cnót tych udziela Bóg wraz z łaską uświęcającą. Dają one zdolność realizowania czynów nie tylko moralnie dobrych, ale i zasługujących na nagrodę wieczną.

Cnoty sprawiają, że człowiek w swych zasadniczym wyborze (optio fundamentalis) wykracza poza chwilowe uczucia i nastroje, buduje w sobie trwałą postawę i przez to rozwija i osiąga wolność. Posiadać cnoty to nie być zdeterminowanym przez własne popędy lub namiętności ani przez naciski społeczne lub wyroki przypadku i okoliczności, to zachowywać krytyczny stosunek do tych czynników oraz tak je wykorzystywać i kształtować, żeby służyły zachowaniom zharmonizowanym z głównym celem ludzkiego życia, niezależnie od tego, jak się go pojmuje (jako stan duchowej czystości, moralnej doskonałości, szczęścia, życzliwego współżycia z innymi).

Cnoty widziane z zewnątrz jako formy ludzkiego zachowania kryją w sobie pewną dwuznaczność. Mogą być wyrazem wewnętrznej postawy człowieka lub zaledwie przejawem zewnętrznego dopasowania się do oczekiwań społecznych. Brak jakiejś cnoty nie musi być oznaką moralnej nieprawości; może być przejawem niezawinionego wadliwego rozwoju psychicznego (przygnębienie, strachliwość, agresywność). Konkretne postaci cnót oraz ich społeczna ocena zależą w pewnym stopniu od zmiennych okoliczności historycznych. Dlatego dla moralnej oceny cnót potrzebne jest jakieś kryterium nadrzędne. W etyce stoickiej był nim porządek natury, w etyce chrześcijańskiej są nim cnoty teologiczne, w których człowiek urzeczywistnia swoje odniesienie do Boga. W perspektywie religijnej wszystkie cnoty mogą zostać pojęte jako wyraz relacji do Boga.

\section{Rozsądek i umiar}

Przy charakterystyce rozsądku nie sposób nie sięgnąć do języka starogreckiego oraz do łaciny. W języku greckim istnieje kilka terminów od- 
noszących się do rozsądku, a co za tym idzie kilka sposobów rozumienia i realizowania samej cnoty. Jeden z nich wyraża termin sophrosyne ${ }^{8}$. Sophrosyne pojawia się w tekstach Homera i oznacza rozwagę, podporządkowanie dyscyplinie, zdrowy rozsadek, dobry rozum. W VII i VI wieku p.n.e. pojęcie to nabiera nowego odcienia znaczeniowego i zbliża się do pojęcia umiaru, panowania nad sobą, powściągliwości. W starożytności panowało przekonanie, że człowiekiem rozsądnym jest ktoś, kto domaga się od innych tego, co mu się od nich słusznie należy ze względu na jego urodzenie lub zasługi. Sophrosyne była uznawana za zdolność do właściwej oceny swojego statusu społecznego, za rozumne rozpoznanie własnych możliwości (i pragnienie osiągnięć na ich miarę), za rodzaj samowiedzy i samoświadomości połączony z umiejętnością panowania nad własnymi emocjami, strachem lub wygórowanymi ambicjami. Sophrosyne uchodziła za piękną i słuszną alternatywę dla życia wydanego na pastwę namiętności, takich jak pożądanie i lęk ${ }^{9}$.

Inny grecki termin odnoszący się do rozsądku to phronesis. Pojęcie to oznaczało mądrość praktyczną i umiejętność realizowania prawdziwej sprawiedliwości. Phronesis pozwalała rządzić państwem i ustanawiać sprawiedliwe prawa. Była to też umiejętność oceniania, czy to, co zazwyczaj słuszne (słuszne w teorii), jest słuszne w tej konkretnej sytuacji. Phronesis oznaczała również praktyczną zdolność osiągania szczęścia i zadowolenia, a także wyznaczania sobie celów i dobierania do nich najwłaściwszych, najskuteczniejszych środków, znajomość rzeczy, do których należy dążyć, oraz tych, których należy unikać („należyte rozumienie wszystkich własnych spraw"10). Phronesis była zdolnością do czynów zgodnych z własnymi moralnymi przekonaniami oraz umiejętnością uzgadniania własnych słów i czynów. Arystoteles odróżnił phronesis od wiedzy teoretycznej i umiejętności praktycznych ${ }^{11}$.

8 Zob. P. Paczkowski, Rozsądek, w: Cnoty. Eseje z filozofii kultury, red. M. Żardecka-Nowak, W. M. Nowak, Rzeszów 2016, s. 45-61.

9 Por. D. Dembińska-Siury, Człowiek odkrywa człowieka, Warszawa 1991, passim.

10 Arystoteles, Etyka nikomachejska, dz. cyt., s. 199.

11 „Rozsądek, czyli mądrość praktyczna, dotyczy spraw ludzkich i tych, nad którymi można się namyślać; mówimy bowiem, że rzeczą człowieka rozsądnego jest przede wszystkim dobry namysł, 
Z kolei język łaciński operuje terminem prudentia (roztropność). Prudentia otwiera katalog cnót kardynalnych. Pozwala ocenić każdą sytuację i w zależności od okoliczności zaleca ostrożność lub śmiałość, ma też zdolność pobudzania woli do czynów, przekonując, że ten właśnie czyn doprowadzi do pożądanego dobra. Chrześcijanin kierujący się roztropnością radzi się własnego sumienia, szuka we własnym doświadczeniu, ale też opiera się na nauce Kościoła, słucha rad osób duchownych, a przede wszystkim otwiera się na przewodnictwo Ducha Świętego (wsłuchuje się w swego Ducha) ${ }^{12}$. Roztropność to wyczucie moralne wsparte na wierze i inspiracji płynącej „z góry”. Człowiek roztropny trafnie ocenia wartość rzeczy ziemskich i boskich. Roztropność jest cnotą, która uzdalnia rozum praktyczny do rozeznawania każdej okoliczności życiowej, wyboru prawdziwego dobra i doboru środków do jego realizacji. Pismo Święte podkreśla wagę roztropności: „Człowiek rozumny na kroki swe zważa” (Prz 14, 15); „Bądźcie więc roztropni, trzeźwi i gotowi do modlitwy” (1 P 4, 7); „Bądźcie rozważni jako węże” (Mt 10, 6). Roztropność nie ma nic wspólnego z nieśmiałością, strachem, dwulicowością, udawaniem. Święty Tomasz z Akwinu określił roztropność jako zasadę wszelkiego działania ${ }^{13} \mathrm{i}$ „,woźnicę cnót” (auriga virtutum), która kieruje pozostałymi ludzkimi przymiotami, wyznacza im zasady i miary oraz wpływa bezpośrednio na sąd sumienia. Podkreślał, że człowiek roztropny umiejętnie wybiera sposób postępowania, porządkuje swoje czyny, bezbłędnie stosuje zasady moralne do poszczególnych przypadków, przezwycięża swoje wątpliwości dotyczące dobra i zła. Święty Tomasz w swej etyce wypracował rozgałęzioną klasyfikację cnót umysłowych i wolitywnych. Pisał: „Cnota ludzka to sprawność doskonaląca człowieka do dobrego działania. W człowieku zaś są tylko dwa źródła czynności ludzkich, a mianowicie umysł i pożądanie. Każda więc cnota doskonali jeden z tych dwóch czynników. Jeśli doskonali umysł w dziedzinie teoretycznej lub praktycznej

a nikt nie namyśla się nad tym, co nie może być inaczej lub co nie ma żadnego celu; celem zaś jest dobro, które ma być osiągnięte przez działanie" (Arystoteles, Etyka nikomachejska, dz. cyt., s. 200).

12 Zob. Katechizm Kościoła Katolickiego, Poznań 2012, s. 349-359.

13 Św. Tomasz z Akwinu, Suma teologiczna, t. 17: Roztropność (2-2, 47-56), przeł. ks. dr S. Bełch, London 1964, q. 47, a. 2, s. 6-8. 
w stosunku do dobra, będzie cnotą umysłową (dianoetyczną), jeśli zaś doskonali pożądanie będzie cnotą obyczajową" ${ }^{14}$. Cnoty dianoetyczne usprawniają umysł do poznawania prawdy, lecz przyporządkowane są ostatecznie realizacji dobra, ponieważ dobroć jest obiektywną cechą (doskonałością) bytów. Nic nie może być chciane, jeśli uprzednio nie zostało poznane. Teoretyczne cnoty umysłowe to pojętność (sprawność w tworzeniu pojęć i sądów), wiedza (biegłość w rozumowaniu), mądrość (sprawność w docieraniu do ostatecznych podstaw prawdy) i roztropność (sprawność w rozpoznawaniu dobra, ku któremu należy się kierować). Akwinata wymienia aż dziewięć umiejętności składających się na cnotę roztropności: pamięć, spostrzegawczość, bystrość, pouczalność, zdrowy rozsądek, zapobiegliwość, przezorność, oględność, ostrożność, staranność. Praktyczne cnoty umysłowe to sprawności w pracy artystycznej i technicznej (sztuki).

Zbiór cnót obyczajowych (etycznych) doskonalących moralne dążenia człowieka otwiera roztropność - ta sama cnota, która zamykała zestaw cnót dianoetycznych. Roztropność w tym zestawieniu jest rozumiana jako sprawność umysłu w wynajdywaniu środków służących do osiągania dóbr przyporządkowanych ostatecznemu celowi człowieka. Roztropność doskonali wolę, umacnia jej trwałość, umożliwia kierowanie sobą i innymi. Święty Tomasz wyróżnia roztropność osobistą, rodzinną i społeczną. Bez prawego umysłu kierującego wszelkim działaniem praktykowanie innych cnót staje się niemożliwe.

Kolejne cnoty kardynalne to sprawiedliwość (stałe nastawienie woli, by oddać każdemu, co mu się słusznie należy), męstwo (sprawność w osiąganiu dóbr trudnych) oraz umiarkowanie. Umiarkowanie rozumiane jest przez św. Tomasza jako sprawność w opanowaniu wszelkich popędów (np. do zachowania życia i do jego przekazania). Na cnotę umiaru składa się nie tylko umiar w odżywianiu się i piciu oraz skromność w sferze płci, ale także łagodność, pokora, cierpliwość, wesołość i umiejętność

14 Św. Tomasz z Akwinu, Suma teologiczna, t. 11: O sprawnościach (1-2, 49-70), przeł. o. F. W. Bednarski, London 1965, q. 58, a. 3, s. 69-70. 
bawienia się. Umiar to cnota znajdująca się w bliskiej relacji z roztropnością i sprawiedliwością.

W starożytnej Grecji umiar był nie tylko cnotą, lecz stylem życia. Antyczna zasada głosiła: „znaj miarę, miara jest najlepsza”. Arystoteles podkreślał znaczenie złotego środka ${ }^{15}$; zalecał unikanie wszelkich form radykalizmu, niezależność od silnych emocji i wolność od skrajności jako szkodliwych lub szpetnych. Za przejawy skrajności uważał złość, cierpiętnictwo, porywczość, niezdolność do gniewu, skąpstwo, rozrzutność, tchórzostwo, brawurę itd. Podążanie drogą cnoty oznaczało według niego stosowanie zasady umiaru - „Tak tedy każdy, kto się rozumie na rzeczy, unika nadmiaru i niedostatku, szuka natomiast środka i środek wybiera, i to nie środek samej rzeczy, lecz środek ze względu na nas"16. Cnoty takie jak łagodność, hojność, męstwo i inne, są nierozerwalnie związane z umiarem, gdyż stanowią złoty środek pomiędzy wadliwymi skrajnościami.

Stoicy szczególnie cenili cnotę opanowania, spokoju, umiaru oraz umiejętność zachowania równowagi duchowej pośród nawet najbardziej niesprzyjających okoliczności (apatheia, aequanimitas). Starali się oprzeć swoje życie na rozumowych zasadach, unikając wszelkich skrajności i silnych emocji. Marek Aureliusz w Rozmyślaniach wyraża zadowolenie $\mathrm{z}$ tego powodu, że los obdarzył go łagodnością i równym usposobieniem $^{17}$. Horacy głosił pochwałę życia przyjemnego i zwyczajnego (aurea mediocritas - złota przeciętność). Apoteozę zasady umiaru znajdziemy też u licznych polskich autorów, takich jak np. renesansowi poeci: Mikołaj Rej (1505-1569) czy Jan Kochanowski (1530-1584). Współczesny polski filozof - o. Józef Maria Bocheński (1902-1995) - również zalecał umiar $\mathrm{w}$ korzystaniu $\mathrm{z}$ dóbr i przyjemności tego świata ${ }^{18}$. Z umiarkowaniem łączy się powściągliwość, skromność, przezorność oraz poczucie włas-

15 Zob. Arystoteles, Etyka wielka, w: Arystoteles, Dzieła wszystkie, t. 5, dz. cyt., s. 320; Arystoteles, Etyka nikomachejska, dz. cyt., s. 142; Arystoteles, Etyka eudemejska, w: Arystoteles, Dzieła wszystkie, t. 5, dz. cyt., s. 446.

16 Arystoteles, Etyka nikomachejska, dz. cyt., s. 111.

17 Zob. Marek Aureliusz, Rozmyślania, przeł. M. Reiter, Warszawa 1958, s. 3.

18 Zob. J. M. Bocheński, Podręcznik mądrości tego świata, Kraków 1992, s. 49-54. 
nej godności. Arystoteles zachęcał do tego, by wprowadzać w życiu ład zarówno w rzeczach ważnych, jak i błahych ${ }^{19}$.

Zdaniem św. Tomasza z Akwinu cnocie umiaru (temperantia) towarzyszy szereg cnót pomocniczych ograniczających ambicję, apetyt, pożądanie, gniew, próżność itd. Umiar jest istotą wszystkich cnót z wyjątkiem cnót teologicznych. Tylko w przypadku wiary, nadziei i miłości nie można zgrzeszyć nadmiarem. Umiarkowanie, które dotyczy pożądań osobistych, jest jako takie cnotą niższą niż odwaga i sprawiedliwość, które odnoszą się do dobra ogółu. Jest też cnotą najmniej heroiczną, skupioną na tym, by opanować wszelkie pożądania, pragnienia, gniew i złość, a wykształcić łaskawość (clementia) i łagodność (monsuetudo) oraz zachować pokorę (humilitas) pozwalającą skutecznie przeciwstawić się pysze (grec. hybris, łac. superbia). Umiar dotyczy nie tylko opanowania przy jedzeniu i piciu, lecz również takich kwestii, jak mniemanie o sobie oraz stawianie sobie celów i wymagań. Łączy się z rozsądkiem, gdyż jest rozumnym używaniem rzeczy, rozwagą samą; sprzeciwia się wszystkiemu, co w człowieku niezgodne $z$ rozumem ${ }^{20}$. Umiar to piękno i harmonia osobowości oraz równowaga życiowa. Tak pojęta cnota umiaru odsyła nas do idei pełni życia i pełni człowieczeństwa.

Michel de Montaigne z wielką atencją pisał o umiarze. Podkreślał, że nawet cnota staje się błędem, gdy praktykować ją zbyt ostro i bezwzględnie ${ }^{21}$. Uważał, że nie mają racji ci, którzy powiadają, że nie może być zbytku w cnocie (igrają tylko pustymi słowami). „Filozofia rozróżnia subtelnie te rzeczy i wie, iż można i nadto kochać cnotę, i unieść się zbyt daleko w sprawiedliwym postępku"22. Człowiek przesadnie nabożny potrafi bardzo zaszkodzić swojej religii; nieumiarkowany w czynieniu dobra zaskakuje, mierzi i stawia wszystkich w kłopocie, cnotliwy ponad miarę wydaje się nie tyle sprawiedliwy, co dziwny. Nawet filozofowanie, które przekracza rozsądne granice, przynosi szkody - „czyni człowie-

19 Zob. Arystoteles, O cnotach i wadach, w: Arystoteles, Dzieła wszystkie, t. 5, dz.cyt., s. 502.

20 Zob. św. Tomasz z Akwinu, Suma teologiczna w skrócie, dz. cyt., s. 609.

${ }_{21}$ Zob. M. de Montaigne, Próby, t. 1, przeł. T. Żeleński (Boy), Warszawa 1985, s. 304.

22 M. de Montaigne, Próby, dz. cyt., s. 304. 
ka dzikim i występnym, wzgardzicielem religii i obowiązujących praw, wrogiem obcowania z ludźmi, wrogiem ludzkich uciech, niezdatnym do spraw publicznych, niezdolnym wspomóc drugiego i samego siebie ani obronić się, gdyby go policzkowano" ${ }^{23}$.

\section{Alegoryczne przedstawienia roztropności i umiaru}

Jedno z nielicznych obrazowych przedstawień cnoty roztropności znajduje się w kaplicy Hiszpanów w kościele Santa Maria Novella we Florencji. Na fresku Andrei de Firenze widzimy niewiastę depczącą rozpustnego tyrana Sardanapala, który ucieleśnia wszelki grzech i rozpasanie. Poza tym w różnych dziełach sztuki napotkać można inne wyobrażenia roztropności - np. w postaci kobiety trzymającej węża, w postaci zwierciadła, księgi, dzbanka z wodą albo odrzuconego worka ze złotem. W Ikonologii Cesare Ripy znajdziemy z kolei trzy wizerunki umiaru. Pierwszy ukazuje kobietę łączącą przeciwieństwa - w jednej ręce trzymającą lwa na łańcuchu, w drugiej - jagnię na sznurku. Drugi obraz przedstawia kobietę, która jedną ręką wskazuje na ziemię, drugą - na niebo, kobieta ta trzyma w prawej ręce wędzidło, w lewej - balans zegarowy, wędzidło symbolizuje powściąganie namiętności, zegar mówi, że wszystko jest czasowo ograniczone; kobiecie towarzyszy słoń, który uchodził za zwierzę zjadające zawsze te samą, umiarkowaną ilość pożywienia. Trzeci obraz umiaru to kobieta $\mathrm{z}$ żółwiem na głowie trzymająca w prawej ręce srebrne wędzidło, w lewej zaś owal, na którym widnieje para koszyków i napis „virtus instrumentum”24.

\section{Roztropność pojmująca tragizm ludzkiego losu}

W pewnym sensie rozsądek i umiar pojąć można jako wyraz głębokiej mądrości dotyczącej połamanej, wewnętrznie splątanej natury ludzkiej. Roztropny jest ten, kto przeżył moment wtargnięcia tragiczności

23 M. de Montaigne, Próby, dz. cyt., s. 304.

24 C. Ripa, Ikonologia, przeł. I. Kania, Kraków 1998, s. 403. 
w swoje życie, kto został pouczony i dał się pouczyć przez nieubłagany tragizm losu. Rozumność tego rodzaju znajduje wyraz w tragedii antycznej (mądrość tragiczna) ${ }^{25}$. Tragiczność zwraca się bezpośrednio do naszych zdolności namysłu ${ }^{26}$. Jest wstrząsem, który pozbawia nas złudzeń serca oraz zadufania w możliwości naszego rozumu. Mądrość tragiczna (prowadząca od tragicznego phronein do praktycznej phronesis), sięgając do niepamiętnych źródeł nieszczęścia, nie dostarcza jednoznacznej nauki, lecz bezlitośnie wystawia człowieka na próbę sytuacyjnego sądu moralnego i zmusza do przeżycia uczucia trwogi i litości. W ten sposób etyczność zostaje pouczona przez tragiczność. Mądrość ta pozwala pojąć, że człowiek nie jest istotą równą bogom, gdy chodzi o siłę działania i umiejętność przewidywania ${ }^{27}$, nie jest też istotą spójną wewnętrznie; ludzki świat wartości nie jest harmonijny i jednorodny. Konflikty i dramatyczne wybory są częścią naszego normalnego życia, a sedno ludzkiego doświadczenia ma charakter agonistyczny. „Rozpoznanie siebie dokonuje się za cenę twardej nauki, zdobywanej w ciągu długiej podróży poprzez te stałe konflikty, których powszechność jest nieodłączna od ich każdorazowo nieprzekraczalnego rozumienia"28 - mówi Paul Ricoeur. Nie ma życia bez straty - wtóruje mu Isaiah Berlin. W życiu ludzkim tak po prostu jest, że niektóre lekcje przychodzą za późno i niektóre lekarstwa nie mogą już nikogo uzdrowić. Nie jest to wynikiem błędu poznawczego ani triumfu namiętności nad rozumem, lecz elementem zwykłej kondycji ludzkiej (Hannah Arendt), naszą moralną nędzą, przed którą nie ma ucieczki. Rozpoznanie tej sytuacji jest wiedzą tragiczną, czyli roztropnością właśnie. Gdy raz objawi nam się owa trudna prawda, musimy się z nią zmagać, a ująć to możemy w niewiele znaczącym pojęciu „konwersji spojrzenia” (w literaturze opisywane jest to jako przejście przez smugę

\footnotetext{
${ }^{25}$ Etyczność zostaje pouczona przez tragiczność. „Klęski nawet w późnym wieku nauczą cię rozumu" (Sofokles, Antygona, przeł. L. H. Morstin, Warszawa 1955, s. 72).

26 Por. P. Ricoeur, O sobie samym jako innym, przeł. B. Chełstowski, Warszawa 2003, s. 402.

27 O kruchości spraw ludzkich i nieprzewidywalności losu pisze np. H. Arendt w dziele Kondycja ludzka, przeł. A. Łagodzka, Warszawa 2000, s. 207-211.

28 P. Ricoeur, O sobie samym jako innym, dz. cyt., s. 397-413.
} 
cienia $\left.^{29}\right)$. Ricoeur mówi, że „tragedia, zakłóciwszy spojrzenie, zmusza człowieka praxis do tego, by nadał nowy kierunek działaniu na swoje własne ryzyko i na własny koszt, kierunek prowadzący do sytuacyjnej mądrości praktycznej, która najlepiej odpowiada mądrości tragicznej”30.

Niewiedza lub zapomnienie o naszej przyrodzonej słabości prowadzi do grzechu pychy, a na poziomie życia politycznego - do despotyzmu i autorytaryzmu. Niekiedy stawia się zarzut filozofii, że programowo zapomina o tragiczności ludzkiego życia. Sokrates uważał, że cnota jest wiedzą (jedną, pełną - intelektualizm etyczny), do której możemy dotrzeć i według której musimy postępować (cnota-wiedza pozwoli nam rozwiązać wszystkie nasze moralne problemy). Arystoteles sformułował doktrynę złotego środka, która miała być panaceum na wszelkie sprzeczności i konflikty targające człowiekiem. Wydaje się jednak, że filozofowie ci, pomimo swego intelektualnego optymizmu, rozumieli, iż w wielu sytuacjach nie można z góry podać słusznej zasady postępowania ani uniknąć tragicznego wyboru. Roztropność tego typu jest dojrzałym stadium moralności prowadzącym od jasnych reguł do moralnego sądu sytuacyjnego. Dojrzała roztropność pojmuje, że źródłem problemów moralnych może być nie tylko ułomność i jednostronność charakterów, lecz również jednostronność moralnych zasad niewspółmierna do złożoności życia.

\section{Wielość ludzkich wad}

Przeciwieństwem roztropności i umiaru są liczne wady. Największą z nich jest pycha (hybris, superbia), która nie zna granic dla swych ambicji i pragnień. Niektóre wady powstają wskutek niedomiaru roztropności; są to: głupota, arogancja, powierzchowność, niedbałość, nieostrożność. Inne wady rodzą się wskutek zwyrodniałego jej nadmiaru; są to: przebiegłość, spryt, chytrość, podstępność. Jednej cnocie odpowiada wiele wad, gdyż

29 Rozstanie z młodzieńczą naiwnością, z przekonaniem o możliwości zrealizowania wszystkich celów i pragnień, pojednania wszystkich ludzi itp. Po przekroczeniu smugi cienia nic nie jest oczywiste, proste ani pewne. Zob. J. Conrad, Smuga cienia, przeł. J. J. Szczepański, Wrocław 1994, passim.

${ }^{30}$ P. Ricoeur, O sobie samym jako innym, dz. cyt., s. 409. 
dróg błędnych może być wiele („błądzić można w sposób rozmaity”31), lecz droga wiodąca do właściwego celu jest tylko jedna. Nieumiarkowanie jest wadą dziecinną - sprowadza nas do poziomu rozkapryszonego dziecka pragnącego wszystkiego, co przyjemne bez względu na dalsze konsekwencje $^{32}$. Arystoteles powiada, że brak umiaru czyni z człowieka niewolnika lub zwierzę ${ }^{33}$. Najbardziej zagraża nam w takich dziedzinach, jak jedzenie i picie (obżarstwo, pijaństwo) oraz przyjemności seksualne (rozpusta). Można powiedzieć, że wszystkie ludzkie wady i grzechy wynikają z braku umiaru: pycha to wygórowane mniemanie o sobie, chciwość to nadmierne pragnienie dóbr materialnych, rozwiązłość to folgowanie pożądaniu seksualnemu, gniew to zaślepienie złością, lenistwo to wyolbrzymianie trudności i zła w świecie itd.

\section{Kryzys etyki cnót}

Wydaje się, że w dzisiejszych czasach próby zainicjowania poważnej i szerokiej dyskusji nad kwestią cnót skazane są na niepowodzenie. Tradycja kształtowania w sobie cnót dawno już się wygasła. Cnoty rycerskie (wysławiane już w epoce Homera, stanowiące sam ideał, wzorzec cnoty), takie jak odwaga, honor, wola walki, dzielność, wytrzymałość, nie znajdują obecnie przestrzeni, w której mogłyby się realizować. Cnoty mieszczańskie, takie jak rzetelność, uczciwość, pracowitość, oszczędność, punktualność, pilność, zamiłowanie do porządku itp., zostały zdyskredytowane i zastąpione przez gloryfikację takich cech, jak spryt, lenistwo i ostentacyjny konsumpcjonizm, które z pewnością nie są cnotami w tradycyjnym rozumieniu. Sama idea cnoty przestała się jawić jako cel warty realizacji.

Przyczyny tego stanu rzeczy są złożone. Źródeł kryzysu można upatrywać w etyce nowożytnej, która obsesyjnie koncentrowała się na logicznym

31 Arystoteles, Etyka nikomachejska, dz. cyt., s. 112.

32 „Wszak w bezrozumnej istocie pragnienie przyjemności jest nienasycone i byle co je rozpala, a zaspokojenie pożądania wzmaga przyrodzona skłonność, jeśli zaś żądze nabiorą siły i gwałtowności, to tłumią w końcu zdolność rozumowania" (Arystoteles, Etyka nikomachejska, dz. cyt., s. 145-146).

${ }^{33}$ Zob. Arystoteles, Etyka nikomachejska, dz. cyt., s. 143. 
uzasadnianiu norm moralnych albo wypalała się w czysto teoretycznych sporach pomiędzy utylitarystami i kantystami i przez to straciła zdolność do inspirowania ludzkich zachowań; inną przyczyną może być oddziaływanie szerokiego wachlarza idei związanych z tzw. ponowoczesnością oferującą grę nieskończenie wieloma możliwościami i dyskredytującą wszelką stałość (w tym stałość cnoty, niezmienność charakteru); poza tym wskazywać można na triumf agresywnej wersji liberalizmu i kapitalizmu wolnorynkowego, rozumu instrumentalnego i powszechnego konsumpcjonizmu.

W wąskich kręgach akademickich specjalistów poważne dyskusje na temat moralności i cnoty nigdy nie ustały ${ }^{34}$. Jednakże ich dywagacje osiągają wysoki stopień intelektualnego wyrafinowania ${ }^{35}$ i jako takie nie mają szansy oddziałać na bieżące życie społeczne. Jednym z nielicznych autorów powracających do idei klasycznie pojmowanych cnót i zarazem próbujących ożywić powszechne pragnienie kształtowania ich w sobie jest Alasdair MacIntyre ${ }^{36}$. Powiada on, że człowiek musi odpowiedzieć sobie na pytanie, w jakiej historii chce być bohaterem i jak ma się zachowywać, aby dobrze odegrać swoją rolę. Dzięki niemu i kilku innym podobnym autorom (np. Elizabeth Anscombe, Bernard Williams ${ }^{37}$ ) mówi się obecnie o renesansie etyki cnót (choć wielu intelektualistom termin „renesans” wydaje się w tym przypadku mocno przesadzony ${ }^{38}$.

Współczesnego człowieka fascynują raczej wady, takie jak egoizm, brawura, pycha, chciwość, nieumiarkowanie, ambicja itp. Są one traktowane jako podłoże postępu, oryginalności, twórczości. Wady te wydają się bardziej autentyczne niż niegdysiejsze cnoty. Nad cnotami ciąży podejrzenie o hipokryzję, gdyż były one nie raz wykorzystywane instrumentalnie

34 Por. G. Ravasi, Powrót do cnót, przeł. A. Wojnowski, Kraków 2012, s. 7; M. Slote, Cnota, w: Przewodnik po współczesnej filozofii politycznej, red. R. E. Goodin, Ph. Pettit, przeł. C. Cieśliński, M. Poręba, Warszawa 1998, s. 820-827.

${ }^{35}$ Por. Etyka i charakter, wybrał i przeł. J. Jaśtal, Kraków 2004, passim.

36 A. MacIntyre, Dziedzictwo cnoty. Studium z teorii moralności, przeł. A. Chmielewski, Warszawa 1996, passim.

37 B. A. O. Williams, Ethics and the Limits of Philosophy, Cambridge, Mass. 1985, passim.

${ }_{38}$ Zob. G. Pence, Teoria cnoty, przeł. P. Łuków, w: Przewodnik po etyce, red. P. Singer, Warszawa 1998, s. 292-302. 
jako argumenty w walce o władzę. Już dla Niccolò Machiavellego było sprawą oczywistą, że przybieranie pozy człowieka cnotliwego jest najskuteczniejszą metodą zdobywania i sprawowania władzy ${ }^{39}$. Friedrich Nietzsche uznał cnotę za formę samozakłamania człowieka co do jego istoty $^{40}$. Poza tym rozmaici krytycy etyki cnót zauważyli, że poruszamy się w kręgu pustych słów: brawurę można ukryć pod pseudonimem odwagi, rozrzutność nazwać można hojnością, wolę zemsty - sprawiedliwością, tchórzostwo odpowiednio zinterpretowane może uchodzić za tolerancję i łagodność itd. Każda cnota ma swój cień w postaci wady, którą kamufluje, albo nawet więcej - każda cnota jest wadą przedstawioną w kłamliwy i pokrętny sposób. Dziś mało kto się troszczy o cnotę i swój charakter. Udane życie utożsamiane jest $\mathrm{z}$ sukcesem zawodowym i ekonomicznym oraz z ostentacyjną konsumpcją.

Współcześnie rozsądek sprowadza się do pragmatycznego wyrachowania i sprytu. Nie sposób odróżnić go od postawy określanej niegdyś mianem cynizmu. Być rozsądnym to nie narażać się na straty i nieprzyjemności (np. nie stawać w obronie słabszych), unikać sytuacji trudnych, zawsze troszczyć się o swoją korzyść itp. Rozsądek okazuje się eufemistyczną nazwą dla egoizmu, konformizmu, tchórzliwej ostrożności, uległości wobec konwencji, braku autentyczności i szczerości itp. Spryt, wygodnictwo, egoizm, oportunizm i lenistwo uznawane są za jego główne przejawy ${ }^{41}$. Rozsądek nie jest niczym innym, niż szlachetnym pozorem ukrywającym nędzne pobudki; polega on na umiejętności konsekwentnego osiągania własnych celów z pominięciem dobra innych ludzi, lecz (o ile to możliwe) przy zachowaniu pozorów przestrzegania zasad i uwzględniania ich dobra ${ }^{42}$.

39 Zob. N. Machiavelli, Książę, przeł. Cz. Nanke, Kęty 2004, s. 70.

40 Samozakłamanie to przybiera, zdaniem Nietzschego, postać metafizyki.

${ }^{41}$ Por. U. Schnabel, Sztuka leniuchowania. O szczęściu nicnierobienia, przeł. V. Grotowicz, Warszawa 2014, s. 215.

${ }^{42}$ Myśliciele starożytni i średniowieczni zdawali sobie sprawę z tego, że spryt może uchodzić za rozsądek, jednocześnie starannie rozróżniali te dwie kwestie od siebie. Twierdzili, że spryt triumfuje tam, gdzie człowiekowi brakuje cnoty, czyli właściwego rozeznania w kwestii tego, co dobre i złe. 
Umiar z kolei traktowany jest jako zamiłowanie do przeciętności i bylejakości. Współczesność zaleca stosowanie zasady: „im więcej, tym lepiej". Nadmiar dotyczy przede wszystkim konsumpcji. W konsumpcji tej nie chodzi o jedzenie (otyłość stała się wręcz przejawem niskiego statusu społecznego), lecz o fetyszyzm towarowy oraz o „pochłanianie” takich dóbr, jak podróże, przygody, wyjątkowe wydarzenia ${ }^{43}$. W mentalności współczesnego człowieka króluje ambicja (pycha), wola wyróżniania się, popisywania, przekraczania granic itp. Może się to wiązać z pewnymi formami ascetyzmu i wyrzeczenia ( $w$ trosce o piękne ciało, zdrowie, dobrą kondycję fizyczną). Bohaterami masowej wyobraźni stają się jednostki pozbawione umiaru, gdy chodzi o pragnienie sławy, zamożności, władzy - nienasycone, próżne, okrutne i złe. Nastał czas karnawału i potlaczu, w którym zasadą jest nadmiar, rozrzutność, rozpasanie, demonstracyjna konsumpcja, eksces, przesada, transgresja i ekstrawagancja ${ }^{44}$. Nieobliczalny, pyszałkowaty sensat (nie zaś człowiek poważny, rozsądny i umiarkowany) stał się atrakcyjnym wzorcem osobowym. Przejawem współczesnej skłonności do nadmiaru jest też zamiłowanie do rozmaitych wyczynów i sportów ekstremalnych ${ }^{45}$. Dzisiejsze społeczeństwo zastąpiło świętych i bohaterów celebrytami i sportowcami ${ }^{46}$. Konsumpcja, wyczyn i ostentacja stały się formami socjalizacji. Konsumowanie i popisywanie się zastępują relacje społeczne i wyznaczają miejsce w społecznej hierarchii. Według Jeana Baudrillarda zjawisko konsumpcji wszędzie rzuca się w oczy, a umiłowanie dóbr materialnych stanowi rodzaj „fundamentalnej mutacji w obrębie ekosystemu, w jakim funkcjonuje gatunek ludzki” ${ }^{47}$. Przedmioty zaczynają dominować nad człowiekiem (spektakl celebracji przedmiotów, obsesja posiadania, antropomorfizacja rzeczy). Życie zamienia się w pasmo nieumiarkowanej konsumpcji

43 Por. A. Aldrige, Konsumpcja, przeł. M. Żakowski, Warszawa 2006, passim.

${ }_{44}$ Por. T. Veblen, Teoria klasy próżniaczej, przeł. J. Frenzel-Zagórska, Warszawa 2008, passim.

45 Por. M. Pacukiewicz, Grań kultury. Transgresje alpinizmu, Kraków 2012, passim.

46 Por. P. Sloterdijk, Pogarda mas, przeł. B. Baran, Warszawa 2012, s. 127.

47 J. Baudrillard, Społeczeństwo konsumpcyjne, jego mity i struktury, przeł. S. Królak, Warszawa 2006, s. 7. 
(kultura konsumpcyjna) $^{48}$. Konsument zastępuje relacje międzyludzkie relacjami z przedmiotami. Zasadą jest szybkość (nabywania) i nadmiar (posiadania). Poczucie przynależności do elity osiąga się przez błyskawiczne konsumowanie odpowiednich dóbr ${ }^{49}$.

W społeczeństwie konsumpcyjnym wszystkiego jest za dużo: artystów, dzieł, mediów, instytucji, atrakcji. Coraz trudniej dokonać jakiegokolwiek wyboru, ponieważ nie wiadomo, co jest ważne, co jest wartościowe ${ }^{50}$. Kultura przesytu i przeładowania jest zarazem (paradoksalnie) kulturą biedy i bezrobocia, w której brak pracy i stałych dochodów jest najbardziej palącym problemem. Cechą współczesnego społeczeństwa konsumpcyjnego jest również pochłanianie wszelkich informacji, niezdolność do ich selekcji, uzależnienie od wielu bodźców medialnych, lęk przed brakiem dostępu do informacji (do Internetu, do telefonu komórkowego). $\mathrm{Na}$ określenie tego typu nadmiernej konsumpcji Tomasz Szlendak posługuje się terminem „infootyłość”. Innym strapieniem współczesnego konsumenta jest paniczny lęk przed niewykorzystaniem atrakcyjnych okazji.

W kulturze konsumpcji dominuje rozproszenie, brak uwagi, nerwica, brak czasu na normalne życie oraz powszechna bylejakość (która wynika z szybkości i zachłanności). Brak roztropności i umiaru staje się rzeczywistym problemem społecznym i kulturowym ${ }^{51}$. Nadmiar obrazów (bodźców wizualnych) skłania do przypuszczenia, że nastał kres ery myślenia i rozumu, rodzi się zaś epoka wideokracji i postmyślenia ${ }^{52}$. Nawet polityka dawno upodobniła się do masowej rozrywki; jest tak jak ona pozbawiona treści; zabawia, absorbuje, pochłania czas, roznieca negatywne

48 Por. Z. Bauman, Konsumowanie życia, przeł. M. Wyrwas-Wiśniewska, Kraków 2009, s. 91.

49 Por. G. Ritzer, Magiczny świat konsumpcji, przeł. L. Stawowy, Warszawa 2004, passim.

50 Por. T. Szlendak, Kultura nadmiaru w czasach niedomiaru, „Kultura Współczesna” 2013 nr 1, s. 8.

51 Z problemem tym próbuje się zmierzyć Peter Fisk w książce Geniusz konsumenta, przeł. P. Konobis, Warszawa 2014. Formułuje tam kilka zaleceń mających ograniczyć konsumpcję, uczynić ją bardziej racjonalną i bardziej moralną (szacunek dla środowiska naturalnego, szacunek dla wolności innych ludzi).

52 Por. G. Sartori, Homo videns. Telewizja i postmyślenie, przeł. J. Uszyński, Warszawa 2007, passim. 
emocje, buduje opozycje, zaognia spory, utrwala wrogość i stereotypy i w ten sposób przysługuje się kulturze nastawionej na konsumpcję $e^{53}$.

\section{Zakończenie}

Wydaje się, że współczesna kultura hałaśliwego nadmiaru i niepohamowanej konsumpcji zmęczona jest sama sobą i oczekuje na jakąś lekcję rozsądku i umiaru, której mogliby jej udzielić ludzie wrażliwi, rozumni i poczuwający się do odpowiedzialności większej niż troska o własne interesy. To pouczenie musiałoby jednak przybrać formę wolną od nieznośnego szkolnego dydaktyzmu, inną niż kaznodziejskie wyrzekania na zepsucie świata, inną też niż zawiłe filozoficzne wywody. Być może najważniejszym obszarem, z którego dotrzeć może do nas tego rodzaju „otrzeźwienie”, jest dzisiaj sztuka (poezja, powieść, film, teatr, performance) poruszająca pospołu rozum i serce, mająca też szansę przemówić do licznych odbiorców. Nawet najbardziej nieprzejednany konsument zatracający się w uciechach życia nie uniknie szeregu gwałtownych pouczeń przez tragiczność indywidualnych losów oraz tragiczność rozmaitych wydarzeń historycznych. Problem polega jednak na tym, że uwięziony w swym zawinionym infantylizmie może paść ich ofiarą bezwiednie, gdyż nie jest w stanie ich zauważyć ani tym bardziej zrozumieć. Dlatego nieoceniony bywa głos poezji, która zakłóca prosty program życia i ma zdolność otwierania oczu na jego nieprzeczuwane aspekty.

W jednym z wierszy Leopolda Staffa można doszukać się streszczenia historii refleksji nad umiarem i roztropnością oraz mistrzowskiego przemierzenia kilku epok literackich i nawiązania do wcześniejszych autorów:

Żyłem i z rzeczy ludzkich nic nie jest mi obce.

Przeto myśli me, które stoją przy mnie w radzie,

Choć smutne, są pogodne jako starce w sadzie.

I uczę miłowania, radości w uśmiechu,

W łzach widzieć słodycz smutną, dobroć chorą w grzechu,

53 Por. G. Debord, Społeczeństwo spektaklu, przeł. M. Kwaterko, Warszawa 2006, passim. 
I pochwalam tajń życia w pieśni i w milczeniu,

Pogodny mądrym smutkiem i wprawny w cierpieniu ${ }^{54}$.

\section{Bibliografia}

Aldrige A., Konsumpcja, przeł. M. Żakowski, Warszawa 2006.

Arendt H., Kondycja ludzka, przeł. A. Łagodzka, Warszawa 2000.

Arystoteles, Etyka eudemejska, w: Arystoteles, Dzieła wszystkie, t. 5, przeł. D. Gromska,

L. Regner, W. Wróblewski, Warszawa 1996, s. 386-495.

Arystoteles, Etyka nikomachejska, w: Arystoteles, Dzieła wszystkie, t. 5, przeł. D. Gromska,

L. Regner, W. Wróblewski, Warszawa 1996, s. 8-301.

Arystoteles, Etyka wielka, w: Arystoteles, Dzieła wszystkie, t. 5, przeł. D. Gromska, L. Regner, W. Wróblewski, Warszawa 1996, s. 302-385.

Arystoteles, O cnotach $i$ wadach, w: Arystoteles, Dzieła wszystkie, t. 5, przeł. D. Gromska,

L. Regner, W. Wróblewski, Warszawa 1996, s. 496-505.

Aureliusz M., Rozmyślania, przeł. M. Reiter, Warszawa 1958.

Baudrillard J., Społeczeństwo konsumpcyjne, jego mity i struktury, przeł. S. Królak, Warszawa 2006.

Bauman Z., Konsumowanie życia, przeł. M. Wyrwas-Wiśniewska, Kraków 2009.

Bocheński J. M., Podręcznik mądrości tego świata, Kraków 1992.

Conrad J., Smuga cienia, przeł. J. J. Szczepański, Wrocław 1994.

Debord G., Społeczeństwo spektaklu, przeł. M. Kwaterko, Warszawa 2006.

Dembińska-Siury D., Człowiek odkrywa człowieka, Warszawa 1991.

Etyka i charakter, wybrał i przeł. J. Jaśtal, Kraków 2004.

Fisk P., Geniusz konsumenta, przeł. P. Konobis, Warszawa 2014.

Gigon O., Główne problemy filozofii starożytnej, przeł. P. Domański, Warszawa 1996.

Katechizm Kościoła Katolickiego, Poznań 2012.

Herbut J., Cnota, w: Leksykon filozofii klasycznej, red. J. Herbut, Lublin 1997, s. 90-91.

Machiavelli N., Książę, przeł. Cz. Nanke, Kęty 2011.

MacIntyre A., Dziedzictwo cnoty. Studium z teorii moralności, przeł. A. Chmielewski, Warszawa 1996.

54 L. Staff, Przedśpiew, w: L. Staff, Poezje, Lublin 1986, s. 69. 
MacIntyre A., Natura cnót, „Znak” 1994 nr 8 (46), s. 36-46.

Montaigne M. de, Próby, t. 1, przeł. T. Żeleński (Boy), Warszawa 1985.

Pacukiewicz M., Grań kultury Transgresje alpinizmu, Kraków 2012.

Pence G., Teoria cnoty, przeł. P. Łuków, w: Przewodnik po etyce, red. P. Singer, Warszawa 1998, s. 292-302.

Ravasi G., Powrót do cnót, przeł. A. Wojnowski, Kraków 2012.

Ricoeur P., O sobie samym jako innym, przeł. B. Chełstowski, Warszawa 2003.

Ripa C., Ikonologia, przeł. I. Kania, Kraków 1998.

Rist J. M., Human Value. A study of Ancient Philosophical Ethics, Leiden 1982.

Ritzer G., Magiczny świat konsumpcji, przeł. L. Stawowy, Warszawa 2004.

Sartori G., Homo videns. Telewizja i postmyślenie, przeł. J. Uszyński, Warszawa 2007.

Schnabel U., Sztuka leniuchowania. O szczęściu nicnierobienia, przeł. V. Grotowicz, Warszawa 2014.

Slote M., Cnota, w: Przewodnik po współczesnej filozofii politycznej, red. R. E. Goodin, Ph. Pettit, przeł. C. Cieśliński, M. Poręba, Warszawa 1998, s. 820-827.

Sloterdijk P., Pogarda mas, przeł. B. Baran, Warszawa 2012.

Sofokles, Antygona, przeł. L. H. Morstin, Warszawa 1955.

Szlendak T., Kultura nadmiaru w czasach niedomiaru, „Kultura Współczesna” 2013 nr 1, s. 7-26.

Szostek A., Pogadanki z etyki, Częstochowa 1993.

Ślipko T., Zarys etyki ogólnej, Kraków 1974.

Św. Tomasz z Akwinu, Suma teologiczna w skrócie, skrót i objaśnienia F. W. Bednarski OP, Warszawa 2004.

Św. Tomasz z Akwinu, Summa theologiae, przeł. ks. dr S. Bełch, London 1964. Veblen T., Teoria klasy próżniaczej, przeł. J. Frenzel-Zagórska, Warszawa 1998. Williams B. A. O., Ethics and the Limits of Philosophy, Cambridge, Mass. 1985. Woroniecki J., Katolicka etyka wychowawcza, t. 2/1, Lublin 1986.

\section{Abstrakt}

\section{Znaczenie rozsądku i umiaru w życiu jednostki i społeczeństwa}

Artykuł rozpoczyna się od rozważań natury ogólnej na temat pojęcia cnoty oraz etyki cnót. Następnie omówione są dwie podstawowe cnoty etyczne - umiar i rozsądek - w wer- 
sjach typowych dla filozofii antycznej oraz myśli chrześcijańskiej. W kolejnej odsłonie ukazany jest rozsądek jako mądrość tragiczna, o której poucza nas antyczna tragedia, po czym prezentowana jest współczesność jako okresu kryzysu etyki cnót. Wskazuje się na kilka możliwych źródeł tego kryzysu. Skutkiem kryzysu jest triumf kultury konsumpcyjnej. Można powiedzieć, że zatomizowane, schorowane społeczeństwo i osamotniona, infantylna jednostka cierpią na chroniczny brak rozsądku i umiaru. W zakończeniu formułuje się wniosek, że remedium na tę dolegliwość może być sztuka, która porusza umysły i serca i dociera do licznych odbiorców, w szczególności zaś poezja, która jest w stanie skutecznie doprowadzić do konwersji naszego spojrzenia na życie.

\section{Słowa klucze}

cnota, etyka cnoty, konsumpcja, rozsądek, społeczeństwo konsumpcyjne, umiar

\section{Abstract \\ The Meaning of Reason and Moderation in Individual and Social Life}

The paper begins with general considerations on the idea and the ethics of virtue. Next, two of the analyzed virtues - reason and moderation - are described in the way typical for ancient philosophy and Christian thought. Then reason is presented as a tragic wisdom, effectively taught by the ancient tragedy. In the next part of this paper we proceed to the presentation of contemporary times, conceived as a period of crisis of values and as the crisis of ethics of virtue. Some possible reasons of this crisis are enumerated. The triumph of the consumer culture turns out to be the result of the crisis. We can say that the atomized and ill society, as well as solitary and childish individuals suffer from the chronic lack of virtue, understood mainly as reason and moderation. The remedy for this condition may by art, because it is able to move our reason and heart and to reach numerous recipients. The best part of art is poetry, because it is able to cause the conversion of our point of view on our life.

\section{Keywords}

virtue, ethics of virtue, consumption, common sense, consumer society, moderation 